\title{
INFLUENCE OF EXERCISE TESTING IN GASTROESOPHAGEAL REFLUX IN PATIENTS WITH GASTROESOPHAGEAL REFLUX DISEASE
}

\author{
Influência do teste de esforço no refluxo gastroesofágico em portadores de doença do refluxo gastroesofágico
}

Antonio Moreira MENDES-FILHO, Joaquim Prado Pinto MORAES-FILHO, Ary NASI, Jaime Natan EISIG, Tomas Navarro RODRIGUES, Ricardo Correa BARBUTTI, Josemberg Marins CAMPOS, Décio CHINZON

From the Departamento de Gastroenterologia, Universidade de São Paulo, Faculdade de Medicina, São Paulo, SP, Brazil ((Department of Gastroenterology, University of São Paulo, School of Medicine, USP, Brazil)
ABSTRACT - Background: Gastroesophageal reflux disease is a worldwide prevalent condition that exhibits a large variety of signs and symptoms of esophageal or extra-esophageal nature and can be related to the esophagic adenocarcinoma. In the last few years, greater importance has been given to the influence of physical exercises on it. Some recent investigations, though showing conflicting results, point to an exacerbation of gastroesophageal reflux during physical exercises. Aim: To evaluate the influence of physical activities in patients presenting with erosive and non erosive disease by ergometric stress testing and influence of the lower esophageal sphincter tonus and body mass index during this situation. Methods: Twenty-nine patients with erosive disease (group I) and 10 patients with nonerosive disease (group II) were prospectively evaluated. All the patients were submitted to clinical evaluation, followed by upper digestive endoscopy, manometry and $24 \mathrm{~h}$ esophageal $\mathrm{pH}$ monitoring. An ergometric testing was performed $1 \mathrm{~h}$ before removing the esophageal $\mathrm{pH}$ probe. During the ergometric stress testing, the following variables were analyzed: test efficacy, maximum oxygen uptake, acid reflux duration, gastroesophageal reflux symptoms, influence of the lower esophageal sphincter tonus and influence of body mass index in the occurrence of gastroesophageal reflux during these physical stress. Results: Maximum oxigen consumption or VO 2 max, showed significant correlation when it was $70 \%$ or higher only in the erosive disease group, evaluating the patients with or without acid reflux during the ergometric testing $(p=0,032)$. The other considered variables didn't show significant correlations between gastroesophageal reflux and physical activity $(p>0,05)$. Conclusions: 1$)$ Highly intensive physical activity can predispose the occurrence of gastroesophageal reflux episodes in gastroesophageal reflux disease patients with erosive disease; 2) light or short sessions of physical activity have no influence on reflux, regardless of body mass index; 3) the lower esophageal sphincter tonus does not influence the occurrence of reflux disease episodes during exercise testing.

\section{Correspondence:}

Antonio Mendes Moreira Filho

E-mail : moreiraantonio6@gmail.com

Financial source: none

Conflicts of interest: none

Received for publication: 06/08/2013

Accepted for publication: $28 / 11 / 2013$
RESUMO - Racional: A doença do refluxo gastroesofágico é afecção com elevada prevalência em todo o mundo, que apresenta grande variedade de sinais e sintomas esofagianos ou extra-esofágico, podendo ter entre suas complicações o adenocarcinoma esofágico. Nos últimos anos, maior importância tem sido dada à influência dos exercícios físicos na sua patogênese. Algumas investigações recentes, embora com resultados conflitantes, apontam para agravamento do refluxo gastroesofágico durante eles. Objetivos: Avaliar a influência da atividade física em pacientes com doença erosiva e não erosiva através do teste ergométrico de esforço, e ainda, a relevância do tônus do esfíncter esofagiano inferior e do índice de massa corpórea durante esta situação. Métodos: Vinte e nove pacientes com doença do refluxo erosiva (grupo I) e 10 com não-erosiva (grupo II) foram avaliados prospectivamente. Todos foram submetidos à avaliação clínica, seguida pela endoscopia digestiva alta, manometria e $\mathrm{pH}$-metria esofágica de 24 horas. Um teste ergométrico foi realizado uma hora antes de retirar a sonda de $\mathrm{pH}$ metria. Durante ele as seguintes variáveis foram analisadas: eficácia do teste, o consumo máximo de oxigênio ou $\mathrm{VO}_{2}$ max, tempo de refluxo ácido, sintomas de refluxo gastroesofágico, influência do tônus do esfíncter esofágico e do índice de massa corporal na ocorrência de refluxo gastroesofágico durante esta situação. Resultados: $\mathrm{VO}_{2}$ max apresentou correlação significativa, quando foi maior ou igual a 70\%, apenas no grupo doença erosiva, avaliando os pacientes com ou sem refluxo 
DESCRTORES - Refluxo gastroesofágico. Teste de esforço. Exercício. Motilidade gastrointestinal ácido durante o teste ergométrico $(p=0,032)$. As demais variáveis consideradas não demostraram correlação significativa entre a ocorrência de refluxo gastroesofágico e a atividade física ( $p>0,05)$. Conclusões: 1 ) Atividade física de alta intensidade pode predispor à ocorrência de episódios de refluxo gastroesofágico em pacientes em portadores da forma erosiva; 2) atividade física de baixa intensidade ou de curta duração não exercem influência, independentemente do índice de massa corpórea; 3) o tônus do esfíncter esofagiano não influencia na ocorrência de episódios de refluxo gastroesofágico durante atividade física.

\section{INTRODUCTION}

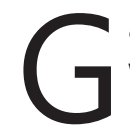
astroesophageal reflux disease (GERD) was defined by the consensus of Montreal as a condition developed when the reflux of stomach contents causes uncomfortable symptoms and complications ${ }^{25}$. It has important medical-social feature due high prevalence rates, estimated at $20 \%$ in the USA adult population and similar rates in Europe ${ }^{23}$. In Brazil, a population study shows a prevalence around $12 \%$.

The pathophysiology of GERD is multifactorial, highlighting the transient loweresophageal sphincter (LES) relaxation and changes in its tone (hypotonia).

Several studies 5,6,21,22 have shown that depending on the intensity of physical activity performed symptoms related to the upper digestive tract (heartburn, regurgitation, belching,) are common, being present in up to $58 \%{ }^{6}$. How physical exercise influences on its occurrence, however, remains unclear. Publications suggest three possible mechanisms: gastroesophageal motor disorders resulting from reduced mesenteric blood flow 21,22 , endocrine-metabolic changes ${ }^{20}$ and increased abdominal pressure correlated to some physical activity ${ }^{6}$. Other possible causes have been evaluated, such as changes in the esophagogastric junction and the LES tone (hypotonia) ${ }^{19}$.

Most studies on the subject were made in athletes and healthy, asymptomatic individuals, and few recent evaluations of the exercise training effects in patients with GERD ${ }^{12}$. The hypothesis of the authors is that symptoms and reflux episodes induced by exercise are more frequent and symptomatic in patients with GERD, when compared to those that occur during their usual activities.

The primary objective of this study was to evaluate the influence of physical activity, through the ergometric stress testing (EST) in the occurrence of gastroesophageal reflux (GER) in patients with GERD, comparing the erosive and non-erosive forms of the disease. A secondary objective was evaluate the influence of the lower sphincter pressure and body mass index (BMI) in their occurrence.
METHODS

The study was conducted in accordance with the principles of the Declaration of Helsinki. The protocol was approved by the ethical-scientific committee of the Department of Gastroenterology and review committee of research projects at the Hospital das Clínicas (Cappesq), with the assent No 0615/07. After the study, patients continued to be followed as outpatient of the Department of Gastroenterology, Hospital das Clínicas, FMUSP.

In a prospective study, were evaluated 39 adult patients aged between 18 and 50 years old, both genders, coming from the ambulatory of esophageal and gastric diseases from the Hospital das Clinicas, School of Medicine, University of São Paulo São Paulo, SP, Brazil, with typical symptoms (heartburn or regurgitation more than three times a week). According to the endoscopic findings, they were divided into two groups: Group I - 29 patients with erosive esophagitis and Group II 10 patients with the non-erosive reflux disease.

Based on BMI, patients were weighted and classified according to the classification of the World Health Organization ${ }^{2}$, namely: normal or healthy individuals - those with BMI between 19 and $24.9 \mathrm{~kg} / \mathrm{m}^{2}$; overweight - those with BMI between $25-30 \mathrm{~kg} / \mathrm{m}^{2}$; considered obese - those with $B M I>30 \mathrm{~kg} / \mathrm{m}^{2}$. In this study, patients had only grade I obesity.

The occurrence of GERD was assessed by performing $\mathrm{pH}$ monitoring, comparing the occurrence of this phenomenon during the patients' daily activities (excluding the sleeping period) and during the EST.

The patients were submitted to the following procedures: on the first day it was conduced an upper endoscopy to confirm or refute the presence of peptic erosions; on the second, it was performed esophageal manometry to localize LES precisely for correct positioning of the $\mathrm{pH}$-metry probe and to discard the presence of esophageal dysmotility; on the third, the patient performed treadmill stress test with the $\mathrm{pH}$ probe monitoring, using the modified Heck protocol. The procedure was performed one hour after breakfast, and was concluded when all stages were performed (eight 
total), and stopped when the heart rate reached the maximum pre-determined, or at the request of the patient. To calculate the maximum oxigen consumption (VO2 max) pre-determined standard formulas were used and described by the national consensus ergometry, which are: VO2 $=1.11 \times(60$ $0.55 \times$ age) for men, and $1.11 \times(48-0.37 \times$ age $)$ for women ${ }^{7}$.

To calculate the maximum heart rate predetermined, was used the Karvonen formula ${ }^{17}$, subtracting 220 from the patient's age; submaximal was considered as $85 \%$ of this figure. The test was considered successful when the patient reached at least the submaximal heart rate ${ }^{7}$. After the procedure, the patient remained seated one hour in recovery, and then the $\mathrm{pH}$ probe was removed, for data analysis.

To performed manometry and pH-metry a Alacer ${ }^{\circledR}$ equipament was chosen. For data analysis in the period in which the patient has exercised its usual activities, on periods analysis so supine and during the implementation of EST (considered artifacts); to analyze only during the EST, all other periods were considered artifacts. Drugs that interfere on the motility and/or gastrointestinal secretion - such as prokinetics, calcium channel blockers, antispasmodics, histamine $\mathrm{H} 2$ receptor blockers and proton pump inhibitors - were suspended 10 days earlier the beginning of the study. Patients were instructed to use antacids (aluminum hydroxide) if they presented typical dyspeptic symptoms of GERD.

Were analyzed the following variables: 1) if the effectiveness of EST would influence the occurrence of GER episodes; 2) if the VO2 max level attained would influence the occurrence of reflux episodes during the EST; 3 ) if during the EST, the individual would experience GER episodes compared to usual activities (excluding periods in the supine position); 4) if during the EST there would be more clinical symptoms suggestive of GERD, compared to usual activities; 5 ) if the hypotonia of the LES would influence the occurrence of GER during EST; 6 ) if the overweight or mildly obese have influence on the occurrence of GER episodes during the EST.

\section{Statistical analysis}

To compare categorical variables by group, was used the Fisher exact test, and except for analysis of the symptons' occurrence at rest and at EST, when nonparametric Wilcoxon was used. To analyze the influence of BMI in the two groups together, it was utilized the likelihood ratio test. In every analysis was adopted the significance level of $5 \%(p<0.05)$.
RESULTS

Influence of the EST effectiveness in determining episodes of GER during the same

As shown in Table 1 the efficiency of EST does not influence the occurrence of GER in the two groups $(p>0.05)$.

TABLE 1 - Correlation of the effective exercise testing to predispose gastroesophageal reflux episodes in comparison to the test which was not effective

\begin{tabular}{|l|c|c|c|}
\hline Reflux & Effective & Ineffective & $p^{1}$ \\
\hline Group I & & & \\
\hline Absent & 14 & 6 & 0,382 \\
\hline Present & 8 & 1 & \\
\hline Grupo II & & & \\
Absent & 8 & 1 & 1,000 \\
\hline Present & 1 & 0 & \\
\hline
\end{tabular}

${ }^{1}$ Fisher's exact test

Evaluation of correlation between reflux episodes and physical intensity achieved, as measured by maximum oxygen consumption

The influence of physical intensity to produce an episode of GER in EST, obtained by indirect measurement of VO2 max pre-determined, was evaluated in each group and are shown in Table 2 , where it appears that there was influence of the intensity of physical activity on the occurrence of GER only in patients of Group I, who achieved a VO2 greater than or equal to $70 \%$. They had at least one episode of GER in EST compared with those who have not reached the same group $(p=0.032)$. This correlation was not observed when analyzing Group II $(p>0.05)$.

TABLE 2 - Correlation between maximum oxygen uptake during exercise testing and the presence of gastroesophageal reflux episodes

\begin{tabular}{|c|c|c|c|}
\hline Reflux episodes & VO2 $\geq 70 \%$ & VO2 $<70 \%$ & $p^{1}$ \\
\hline \multicolumn{4}{|l|}{ Group I } \\
\hline Absent & 4 & 16 & \multirow[t]{2}{*}{$0,032 *$} \\
\hline Present & 6 & 3 & \\
\hline \multicolumn{3}{|l|}{ Grupo II } & \multirow{3}{*}{1,000} \\
\hline Absent & 5 & 4 & \\
\hline Present & 1 & 0 & \\
\hline
\end{tabular}

${ }^{1}$ Fisher's exact test

Time percentage comparison of acid reflux during exercise testing and in usual activities

Was assessed whether, in the period in which the patient underwent the EST, there was a proportional increase in the percentage of acid reflux time compared to the same in the usual activities. Table 3 shows that in Group I the vast majority of patients had a percentage of acid reflux time higher in the usual activities; in Group II, this was true in all. Statistical correlation was not significant $(p>0.05)$. 
TABLE 3 - Acid reflux time during exercise testing and usual activities

\begin{tabular}{|cccc|} 
& $\begin{array}{c}\text { \% acid reflux time in ergometric testing higher } \\
\text { than acid reflux time in usual activities }\end{array}$ & \multirow{2}{*}{$\mathbf{p}^{1}$} \\
\hline Grup I & Yes & No & \\
\hline Grup II & 22 & 7 & \multirow{2}{*}{0,158} \\
\hline
\end{tabular}

'Fisher's exact test

Evaluation of clinical symptoms suggestive of gastroesophageal reflux during exercise testing and in usual activities

Was assessed whether, during the EST, the patient reported symptoms of GER and compared with the number of complaints reported in the acid reflux time. Table 4 shows that patients in both groups had a frequency of clinical symptoms suggestive of GER increased in usual activities compared to the period of the EST. There was, in this case, a significant statistical correlation $(p=0.026)$.

TABLE 4 - Number of symptoms during exercise testing and in usual activities

\begin{tabular}{|c|c|c|c|c|c|}
\hline & \multicolumn{4}{|c|}{$\begin{array}{l}\text { Number of symptoms in daily activities } \\
\text { (NSDA) X number of symptoms in } \\
\text { ergometric testing (NSET) }\end{array}$} & \multirow[t]{2}{*}{$\mathrm{p}^{1}$} \\
\hline & NSDA $<$ NSET & $\mathrm{NSDA}=\mathrm{NSET}$ & NSDA $>$ NSET & Total & \\
\hline Grup I & 3 & 10 & 16 & 29 & \multirow{2}{*}{0,026} \\
\hline Grup II & 0 & 4 & 6 & 10 & \\
\hline
\end{tabular}

${ }^{1}$ Nonparametric Wilcoxon test

Evaluation of the influence of tone of LES in the presence of gastroesophageal reflux episodes during exercise testing

The influence of the lower sphincter pressure in episodes of GER in EST was evaluated in both groups. Table 5 shows that there was no significant correlation between the presence of hypotonia of the LES and the presence of GER episodes during EST in the two groups $(p>0.05)$.

TABLE 5 - Evaluation of the influence of tone of LES and the presence of gastroesophageal reflux episodes durina exercise testina

\begin{tabular}{|c|c|c|c|}
\hline \multicolumn{4}{|c|}{ Tone of LES } \\
\hline Reflux & Hypotonia & Normal & $p^{1}$ \\
\hline \multicolumn{3}{|l|}{ Group I } & \multirow{3}{*}{0,106} \\
\hline Absent & 6 & 14 & \\
\hline Present & 6 & 13 & \\
\hline \multicolumn{3}{|l|}{ Group II } & \multirow{3}{*}{0,200} \\
\hline Absent & 1 & 8 & \\
\hline Present & 1 & 0 & \\
\hline
\end{tabular}

Evaluation of the influence of BMI in the presence of gastroesophageal reflux episodes during exercise testing

The influence of BMI in determining episodes of GER in the two groups together during EST was evaluated and is shown in Table 6. Patients with excess weight (overweight and obesity) had no more episodes of reflux related to EST when compared with patients with weight within the normal range $(p>0.05)$. All patients were obese in the classification of mild obesity (grade I).

TABLE 6 - Presence of reflux during exercise, compared to normal-weight individuals and those with overweight or obesity

\begin{tabular}{|c|c|c|c|c|}
\hline & \multicolumn{2}{|c|}{ Reflux } & \multirow{2}{*}{ Total } & \multirow{2}{*}{$p^{1}$} \\
\hline & $\begin{array}{l}\text { Without } \\
\text { reflux }\end{array}$ & $\begin{array}{l}\text { Reflux during } \\
\text { exercise }\end{array}$ & & \\
\hline Normal-weight & $8(88,9 \%)$ & $1(11,1 \%)$ & $9(100 \%)$ & \multirow{3}{*}{0,3994} \\
\hline $\begin{array}{c}\text { Overweight/ } \\
\text { obese }\end{array}$ & $20(66,7 \%)$ & $10(33,3 \%)$ & $30(100 \%)$ & \\
\hline Total & $28(71,8 \%)$ & $11(28,2 \%)$ & $39(100 \%)$ & \\
\hline
\end{tabular}

${ }^{1}$ Likelihood ratio test

\section{DISCUSSION}

In the recent years, several studies have shown that physical activity causes symptoms of $\operatorname{GERD}^{5,6,21,22}$. On one hand this correlation seems to be well documented when performed at strenuous levels ${ }^{13}$, controversy exists regarding the issue when it comes to everyday activities, such as a simple walk. Avidan et $\mathrm{al}^{1}$ in a randomized trial found that a light walk accelerates gastric emptying and reduces the duration of esophageal exposure to acid in reflux agents. Another aspect still controversial is how the exercise would provide the occurrence of reflux episodes.

In this study, was chosen to evaluate patients with both presentation of GERD disease (erosive and non-erosive form) who did not exercise regularly (most). The physical practice was chosen as the treadmill exercise test, which was the method available in the hospital and could be easily used in this population, whose profile was varied.

Being an original study, was found in the literature review no other paper correlating GER with EST; thus was not possible to compare these results with those of other authors regarding the influence of effectiveness. In this study, the vast majority of patients, both in Group I (75.86\%) and Group II (90\%), performed an EST considered effective. Correlation between this variable and the occurrence of GER episodes was not found $(p>0.05)$. On the other hand, the VO2 max is considered the most important physiological measure of cardiorespiratory functional capacity ${ }^{7}$. In this study, was observed a significant correlation between the presence of GER episodes and EST when VO2 was reached at least $70 \%(p=0.032)$ only in Group I. This finding is consistent with those reported by Soffer et al ${ }^{21,22}$, which demonstrated that the higher the level of physical activity, the 
higher the time percentage and number of reflux episodes observed. The importance of intensity of physical activity was also demonstrated in the study of Kraus et al, which found an increase total time at reflux for racing (during $1 \mathrm{~h}$ ), over the same period at rest, being the physical effort performed with a frequency close to the maximum heart rate in individuals conditioned ${ }^{15}$. In this study, were compared proportionally the time percentage when the $\mathrm{pH}$ was less than 4 (acid reflux time \%) during the EST with that observed during their usual activities prior to the procedure. The period in which the individual was in the supine position was excluded from the analysis, understanding that any activity was being conducted and as an attempt to standardize the analysis, not taking the influence of that position into account, since five out of nine (55.55\%) patients who had GER during EST reflux agents were supine or in combination. Only seven out of 29 patients in Group I (24.13\%) and none in Group II had proportionately increased percentage of acid reflux time during physical exercise. It is believed that the observation period of intraesophageal $\mathrm{pH}$ variations has been much longer in this situation than during the EST performed may have favorably influenced a time in GER proportionately larger than in usual activities.

Evaluation of daily activities influence is subject in few papers in literature. Józkow et al in a study involving a larger number of patients $(n=100)$ patients with GERD, compared pH-metric parameters of GER and symptoms, level of daily physical activity performed during a week with the same variables and activities during $24 \mathrm{~h}$ of $\mathrm{pH}$ monitoring completion, and concluded that the usual activities are not associated with changes in these parameters ${ }^{12}$. In this study, patients from both groups had symptoms of GER in higher number in usual activities compared to the period in which underwent EST, this analysis also excluded the period during which the patient was supine. In Group I, of the 29 patients, only three $(10.34 \%)$ reported more clinical complaints during the EST, while in Group II this has not been verified. Statistical significance $(p=0.026)$ to the inverse of the hypothesis to be proven (number of symptoms frequently during the EST). Again, the much longer period of monitoring the usual activities may also have influenced this variable.

Few studies refer symptoms during physical activity and do not compare the frequency of symptoms between the two periods, not allowing a comparison with this study. In relation to clinical complaints reported during exercise, Kraus et al ${ }^{15}$ noted as most frequent complaint episodes of belching. In this study the most frequent symptom of GERD was heartburn during EST in Group I $(n=6)$. In Group II, only one patient had clinical complaints (reported regurgitation) in EST.

In this study, hypotonia of the LES did not influence the occurrence of GER during EST in two groups $(p=0.106$ and $p=0.200$ in Groups I and II respectively). This finding is similar to that reported by Pandolfini et al ${ }^{19}$, a study conducted by $\mathrm{pH}$ monitoring catheter free system (Bravo), which found no influence of the lower sphincter pressure in GERD during exercise, despite having found the influence of espophagogastric junction morphology. Another study in conditioned individuals and no complaints of GER showed no statistical difference in the average resting pressure of LES of those who have had reflux during physical activity ${ }^{15}$. In these two cases, there was none suffering from LES hypotonia in the evaluated groups. In this study, 14 patients had LES hypotonia, with the majority (76.92\%) being overweight or obese. Although the statistical analysis did not show correlation, this finding may have exerted some influence on this variable due to the increased frequency of defects and higher incidence of transient relaxation of lower esophageal sphincter ${ }^{2,3}$.

In this study, BMI did not contributed to determine episodes of GER during EST. When analyzed together $33.3 \%$ of overweight or mildly obese patients had at least one episode of GER related to exercise, while it occurred in normal individuals with $11.1 \%$ of patients. Those who did not have GER at EST, $66.7 \%$ were overweight or mildly obese, and $88.9 \%$ were healthy. Statistical analysis did not show significance $(p>0.05)$. In the literature review conducted was found no studies considering BMI as a precursor of GER during physical activity. Most studies were conducted in subjects conditioned and/or athletes, and it is therefore impossible to compare with the profile of the population included here.

The correlation between physical activity and GERD needs further investigations with larger populations. This study had limitations, especially given to the short time allowed by EST exertion in people of a higher age group and other sedentary. In spite of this restriction, it confirms what has been reported by other authors, the fact of the relationship between physical activity and GER is highly dependent.

\section{CONCLUSIONS}

Exercise of greater intensity, characterized by a EST with $\mathrm{VO}_{2} \geq 70 \%$ of pre-determined, predisposes to episodes of GER in patients with erosive GERD, while lower intensities did not; the lower sphincter 
pressure does not influence the occurrence of GER in patients with GERD during exercise; overweight or mild obesity did not influence the occurrence of GER during exercise.

\section{REFERENCES}

1. Avidan B, Sonnenberg A, Schnell TG, Sontag SJ. Walking and Chewing Reduce Postprandial Acid Reflux. Aliment Pharmacol Ther 2001; $15:$ 151-155.

2. Ayazi S. Jefrey A, Chan LS, DeMeester SR, Ayazi A, Leers JN, Banki, Lipham JC, DeMeester TR, Crokees PF. Obesity and gastroesophageal reflux: Quantify the association between body mass index, esophageal acid exposure, and lower esophageal sphincter status in a large series of patients with reflux symptons. J. Gastrointestinal. Surg. 2009; 13 : 1440-47.

3. Biccas BN, Lemme EMO, Abrahão jr LJ, Aguero GC, Alvariz A, Schechter RB. Maior prevalência de obesidade na doença do refluxo gastro rsofágico erosiva. Arq. Gastroenterol . 2009;1 (vol 46):15-19.

4. Boeckxstaens GE. The lower oesophageal sphincter. Neurogastroenterol Motil. 2005;17(suppl.1 ): 13-2123

5. Clark CS, Kraus BB, Sinclair J, Castell DO. Gastroesophageal reflux induced by exercise in healthy volunteers. JAMA 1989; 261 (24): 3599-3561.

6. Collings KL, Pratt FP et al. Esophageal reflux in conditioned runners, cyclists, and weightlifters. Med. Sci. Sports Exerc 2003; 35 (5): $730-$ 35.

7. Consenso Nacional de Ergometria. Arq Bras Cardiol 1995; 65 (2): 192- 211.

8. Dodds WJ, Dent J, Hogan WJ et al. Mechanisms of gastroesophageal reflux in patients with reflux esophagitis. N Eng J Med. 1982; 302 : 4547-52

9. El-Serag HB. The association between obesity and GERD : A review of the epidemiological evidence. Dig Dis Sci. 2008; 53 ( 9 ): 23072312.

10.Feldman M, Nixon JV. Gastric secretion and emptying in humans. Exercise Physiol. 1982; 53 (4): 851-5418.

11. Histed H, Galbo B , Sonne T, Schwartz J, Fahrenkrug J. Gastroenteropancreatic hormonal changes during exercise. Am J Physiology. 1980; 239: 13-140.

12. Józkow P, Wásko-Czopinik $D$, Dunaska $K$ et al. The relationship between gastroesophageal reflux disease and the level of physical activity. Swiss Med Wky. 2007; 137: 465-470.
13.Joskow $\mathrm{P}$, Wasko-Czopnik $\mathrm{D}$, Mesdras $\mathrm{M}$, Paradowski L. Gastroesophageal Reflux Disease and Physical Activity. Sports Med. 2006; 36 ( 5 ): 385-91.

14.Karvonen JJ, Kentala E, Mustala O. The effects of training on the heart rate. A longitudinal study. Ann. Med. Exp. Biol. Fenn. 1957 ; 35 : 307. 38.

15. Kraus BB, Sinclair J, Castell DO. Gastroesophageal reflux in runners. Annals Int Med 1990; 112 (6): 429-433.

16. Moraes-Filho J P P, Chinzon D, Eisig J et al. Prevalence of hertburn and gastroesophageal reflux disease in the urban Brazilian population. Arq Gastroenterol. 2005; 42: 444-54.

17. Moraes-Filho JPP, Navarro-Rodriguez T, Barbuti R, Eisig J, Chinzon $D$, Bernado W and the Brasilian GERD consensus group. Guidelines for the diagnosis and management of gastroesophageal reflux disease : and evidence-based consensus. Arq Gastroenterol. 2010; 47 (1):99-111.

18. O'Connor AM, Johnston CF, Buchanan KD, Boreham C, Trinick TR, Riddoch CJ. Circuating gastrointestinal hormone changes in marathon running. Int J. Sports med. 1995.16: 283-287.

19.Pandolfino JE, Bianchi LK, Lee TJ, Hirano I, Kahrilas PJ. Esophagogastric junction morphology predicts susceptibility to exercise-inducer reflux. Am J Gastroenterology. 2004; 1430-3624.

20.Riddoch C J. exercise induced gastrointestinal symptomshormonal involvement. Thesis. The Queens University of Belfast, N.Ireland.1990.

21.Soffer EE, Merchant RK, Duethman G, Launspach J, Gisolft C, Adrian TE. Effect of graded exercise on esophageal motility and gastroesophageal reflux in trained athletes. Dig dis Sci. 1993; 38:220-224.

22.Soffer EE, Wilson J et al. Effect of graded exercise on esophageal motility and gastroesophageal reflux in nontrained subjects. Dig Dis Sci 1994; 39 (1): 193-8.

23.Sonnenberg A, El-Serag HB. Clinical epidemiology and natural history of gastroesophageal reflux disease. Yale J Biol Med. 1997; 72: 81-9.

24.Sullivan SN, Champion MC, Christofildes ND, Adrian TE. GI regulatory peptide responses in lon distance runners. Physician Sport Med. 1984; 12: 77-82.

25. Vakil N, van ZanGen SV, Kahrilas P, Dent J, Jones R. The Montreal definition and classication of gastroesophageal reflus disease: $A$ global evidence.Based consensus. Am. J. Gastroenterol. 2006;101: 1900-1920.

26.Van Nieuwenhoven MA, Brouns F, Brumer RJM. The effect of physical exercise on parameters of gastrointestinal function. Neurogastroenterol. Mot. 1999; 11: 431-439. 